\title{
Interdisciplinary Education in Multicultural Environment
}

\author{
Rudite Andersone $^{1}$ Dr. paed.; Ineta Helmane ${ }^{2}$ Dr. paed. \\ University of Latvia, Latvia \\ rudite.andersone@lu.lv ${ }^{1}$; ineta.helmane@ lu.lv $^{2}$
}

\begin{abstract}
Globalization as well as social, economic and political processes in the world affect each individual separately and the society on the whole. Due to changes taking place in the contemporary world more and more attention is paid to multiculturalism. School as a model of a multicultural world can promote people's awareness of what multiculturalism means, what benefits and challenges it brings to people, what knowledge, skills and behaviour are needed for life in a modern multicultural society. Interdisciplinary education is one of the possible ways how the young generation can acquire knowledge and skills necessary for life in the multicultural society of the $21^{\text {st }}$ century to be able to solve the diverse problems, to seek answers to the real-life issues. Thus, the aim of the paper is to analyse the experience of interdisciplinary education in the basic education curricula implemented in the multicultural environment of Latvia.
\end{abstract}

Keywords: interdisciplinary education, multicultural environment, curriculum, school education.

\section{Introduction}

The modern world changes rapidly due to the globalization processes; the knowledge broadens and is integrated. Undoubtedly, this affects the content of education and the choice of teaching/learning methods in the pedagogical process of school. It is no longer the external world that enters the school but the school itself goes out into the surrounding world that requires a broader view on the situations, processes and phenomena. We understand that the most pressing issues of our time, from climate change to mass migration, from global health to the digital revolution, cannot be fully addressed through a single disciplinary or cultural perspective. We must bring together insights from the natural and social sciences, the arts, engineering and humanities to produce explanations, create products, ask new questions, and find solutions to these contemporary issues. We must re-orient from the offer of mono, separate disciplines to the solution of the current issues and problems existing in the modern surrounding environment that demands the combining and integrating the knowledge and skills acquired in different school subjects. Besides, none of the subjects is given the priority and owing to the interdisciplinarity and emphasising the common in the content of different school subjects the possibilities are sought, thus helping learners to see in a natural way the connection between the everyday events and phenomena with the material included in the school textbooks.

The interdisciplinary approach is a key concept to the advancement of school curriculum at all levels. It is now debated whether an interdisciplinary approach is the best course for the curriculum (Jones, 2009). Interdisciplinary education is implemented in the school environment that is becoming more and more multicultural. The rapid migration processes promote the enrichment of the multicultural environment in the world, including Latvia. The children of not only the historically traditional cultures but also children representing the cultures of the new arrivals sit next to each other in the classes. However, the children of the different cultures have to explore and solve similar problems and issues of the surrounding world.

Thus, the aim of the paper is to analyse the experience of interdisciplinary education in the basic education curricula implemented in the multicultural environment of Latvia.

\section{Methodology}

The theoretical basis of the research consists of analysis of literature about: 1) interdisciplinary educational process (Boix-Mansilla, 2010; Duerr, 2008; Letterman, Dugan, 2004; Fox, Baloy, Sens, 2014; Jones, 2009; Kidron, Kali, 2015; Knotts et al., 2009; Matsagouras, 2004; Smith, McCann, 2001; Vasiliki, Panagiota, Stavrakouli, 2016); 2) multicultural environment (Connerley, Pedersen, 2005; Cooper, 2003; Gordina, 2015; Holloway, Green, Livingstone, 2013; Kokemuller, 2016; Lombardo, 2016; Spanhel, 1999; Thompson, Di Tomaso, 1988). Research is based on theoretical methods. Methods include analysis of scientific literature and resources, as well as documents. Therefore, there was carried out research, analysing basic education curricula, stating whether at all or in what way there are included issues of interdisciplinary education in multicultural environment. 


\section{Results and Discussion}

\section{Interdisciplinary education}

The term refers to the teaching principle that seeks the approach of school knowledge through the global study and process of issues. Interdisciplinarity, at first, starts on the level of scientific research and then it extends to the field of education (Matsagouras, 2004; Vasiliki, Panagiota, Stavrakouli, 2016). The priority that is given to review of important issues for learners and the investigative processing of issues makes the interdisciplinary approach pupil-centred both in terms of concept and methodological approach (Matsagouras, 2003; Vasiliki, Panagiota, Stavrakouli, 2016). The interdisciplinary approach allows pupils becoming more involved in their learning and teachers can work toward eliminating discipline lines. Pupils can become independent, confident individuals who "learn how to learn" and develop lifelong learning skills (Duerr, 2008; Jones, 2009).

Interdisciplinary education is characterised as the process in which pupils integrate information, methods, tools, perspectives, possibilities, ideas, concepts and theories from two or more fields in order to create "products", explain the phenomenon or solve problems. Pupils are not able to do it using the means of only one field, such as information, methods, tools, ideas and concepts (Boix-Mansilla, 2010). In interdisciplinary pedagogical process, the problem questions are discerned, the most appropriate ways of problem solution are applied, the approbation of the obtained results is implemented as well as the process of problem question solution results in formulating and analysing what new knowledge and skills have been acquired, what skills and knowledge have been improved, what the contribution to the development of other pupils is. The development of understanding of interdisciplinary teaching/learning of the learning content is determined by such a learning process through which a pupil integrates his/her views and ways of thinking from various fields, facilitating thematic understanding of a particular field (Kidron, Kali, 2015).

The benefits of interdisciplinary teaching and learning are well established (Fox, Baloy, Sens, 2014; Knotts et al., 2009; Letterman, Dugan, 2004; Smith, McCann, 2001). The interdisciplinary approach has many advantages such as expanding pupils' understanding and achievement between all disciplines and enhancing their communication skills. Interdisciplinarity is not only important for the pupil to learn any one single discipline or solve the problem in a synthesized manner, but it also enriches the pupil's lifelong learning habits, academic skills, and personal growth (Jones, 2009). This kind of education aims to develop boundary-crossing skills. Boundary-crossing skills are, for instance, the ability to change perspectives, to synthesize knowledge of different disciplines, and to cope with the complexity (Spelt et al., 2009).

In order to implement the interdisciplinary education, the transversal skills have to be developed first of all as they help to see further the synthesis of the knowledge and skills of different school subjects in the pedagogical process. This is envisaged in the new project devoted to the development of the new teaching/learning content Skola 2030 (School 2030) which anticipates focussing on the following transversal skills in the curriculum: self-cognition and self-management; thinking and creativity; cooperation and participation; digital literacy (Skola 2030..., 2017). The project webpage gives the quotation of A. Schleicher, the head of the OECD Education and skills directorate, that "Nowadays the aim of the school is to develop pupils' ability to learn all through one's life, to think and act in complex situations, to live in the diverse world as an active and responsible citizen. The key of success of the school graduate is not the volume of his/her knowledge but what he/she is able to do with this knowledge." Thus, the focus is on the development of pupil's competences the basis of which is interdisciplinary education. Competences envisage the application of knowledge in diverse situations that are included in integrated programmes because they, in fact, are interdisciplinary and prepare pupils for lifelong learning (Lake, 1994).

The primary goal in the interdisciplinary approach is the inquiry skills. The nature of that inquiry varies and includes hands-on problem-solving activities, the inquiry into a social era or topic, or the inquiry into a theme or issue. On the other hand, it is the similarity in objective, such as cultural awareness, critical thinking, and informed decision making that typically binds the language arts and social science (Farivar, 1993; Mathison, Freeman, 1994; Norton, 1988). Both contexts seek to emulate the real world while providing pupils with an arena for problem solving and decision-making activities (Mathison, Freeman, 1994).

Thus, interdisciplinary education is implemented also through inquiry-based activities and the solution of problem situations in the current separate subject curricula. The knowledge and skills acquired in 
several school subjects as well as transversal skills that become more and more topical are applied in the inquiry and the solution of problem situations if we think about a complex use of the knowledge and skills acquired during the schooling in the life-long and life-broad learning in the society of today and future that is characterised by ethnic and cultural diversity.

\section{Multicultural environment}

Multiculturalism is the reality of today's world - migration processes have touched the society of all countries. It means that different ethnic and racial groups having a different history, language, culture and religious belonging have to coexist in the political boundaries of countries. Nowadays we have to be aware of the turbulent political transformation processes - the British political adviser Robert Cooper admits that "boarders are increasingly irrelevant for postmodern states. Thanks to the missile, the motor car and the satellite, this is a fact of life in the twenty-first century" (Cooper, 2003, 3).

There is still no unified position in using the notion "multicultural". Analysing different publications (Connerley, Pedersen, 2005; Kokemuller, 2016; Thompson, Di Tomaso, 1988) in the context of the multicultural environment different notions relating to the multicultural environment can be found in several sources, for instance: intercultural interaction- in culture, globalization - in politics and economics, diversity - in pedagogy, multicultural workforce - in career management.

The multicultural environment is used speaking both in the aspect of genders, races, religious belonging and cultural differences. Multiculturalism is often described as the notion of diversity. Diversity, according to the definition, concentrates on the different while multiculturalism is more concentrated on the concrete features of different cultures. The discussion about the "correct" definition is still topical. Several researchers (Connerley, Pedersen, 2005; Cox, 1994; Rijsman, 1997) defend the definition of diversity that is based on the inequality of powers, for example, race and gender. T.H. Cox (1994) defines the cultural diversity as the reflection of differences of different population groups in one social system.

The multicultural perspective tries to secure a conceptual framework that separates and singles out the complex process of the diversity which dominates in the society and at the same time ensures the uniformity and cooperation uniting the culturally different people. During the last 20 years multiculturalism is recognized as a powerful tool not only for understanding the groups of unknown people but also for understanding oneself and those with whom we live and work together (Kokemuller, 2016; Lombardo, 2016). Multiculturalism is a transdisciplinary conception that became possible only in the definite social and anthropological context when a relatively broad interdisciplinary conceptual arsenal has already been created in the science and about which the more educated part of the society has been rather well-informed. Besides, there is an accelerated development of science and technologies, the transition from the industrial society to the information society and a rapid use of information technologies in all spheres of life starting already with the childhood. The technology user in the society of wellbeing in the first decade of the $21^{\text {st }}$ century was on average 6-13 years old but in the second decade we are talking already about the digital literacy of 3-4 years young children. (Holloway, Green, Livingstone, 2013; Spanhel, 1999). It deepens and broadens the multicultural environment.

When a society is diverse, it will only stay together as long as its citizens value deep diversity in itself (Gutman, 2003; Fraser, Honneth, 2003; Kymlicka, 2001).

Integrating more and more in the European Union and strengthening the cooperation with other countries leads also to the increase of ethnic diversity in Latvia. According to the data of the Central Statistical Bureau of Latvia the population of Latvia at the beginning of 2017 was 1950 116, including $85.7 \%$ citizens of Latvia, $11.4 \%$ non-citizens of Latvia and approx. $2.9 \%$ people with permanent or temporary residence permits or foreigners (Resident population by citizenship..., 2017). The data of the Central Statistics Bureau, in their turn, reflect the ethnic composition of Latvia's population (Figure 1). 


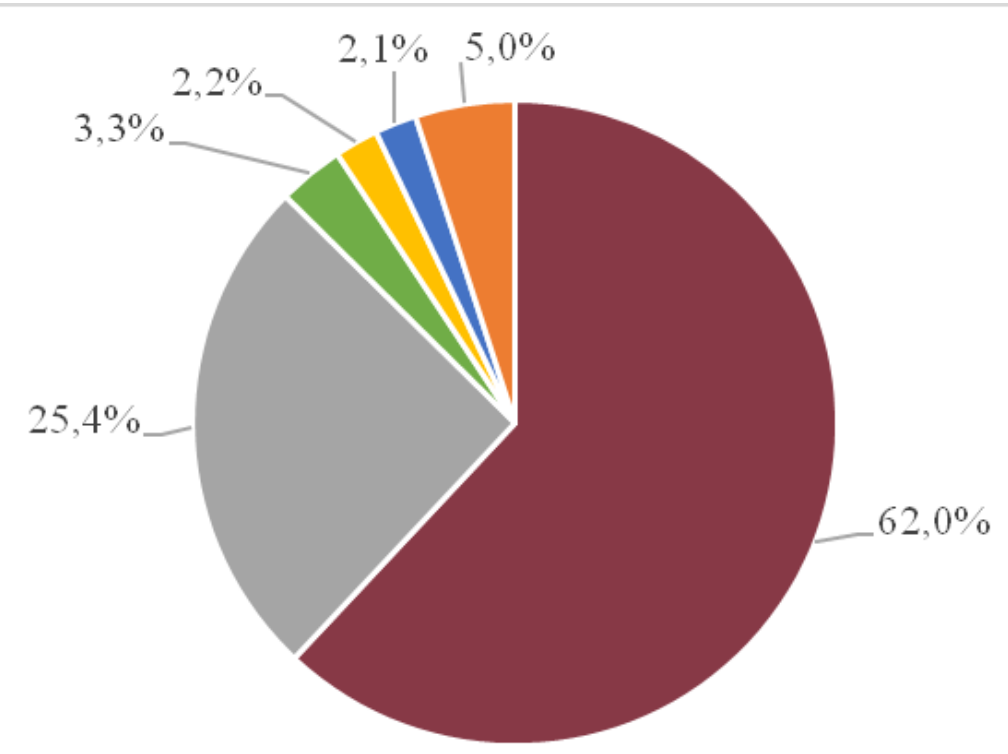

-Latvians " Russians " Belarussians "Ukrainians " Poles " Others

Figure 1. The ethnic composition of Latvia's population at the beginning of 2017 (in percentage)

(Resident population by ethnicity..., 2017).

Part of this population attends education institutions of different types, including general comprehensive schools thus forming the multicultural environment in them. The study performed by M. Gordina (Gordina, 2015) indicates that a bit more than a half of Latvia's young people (54.2\%) are aware of belonging to their culture and its differences from other cultures. Half of the youth (52.6\%) have no prejudices towards the representatives of another religion or race, which means, that the skin colour and religion of other people is not an obstacle for them for the cooperation. Pupils at school in their classes cooperate when exploring, seeking the solutions to the problem situations, discussing, analysing the phenomena and processes in the surrounding environment and the world.

\section{The experience of interdisciplinary education in the basic education curricula implemented in the multicultural environment of Latvia}

In order to study the experience of interdisciplinary education in the basic education curricula that are implemented in the multicultural environment of Latvia the expected learning outcomes at the end of Grade 9 of four basic education curricula that are presented in the webpage of the State Education Centre were analysed. The curricula were chosen from different content areas: from Technology and science area - biology and geography curricula, from Man and society area - history of the world, from Arts area - the literature curriculum. It was found out whether these curricula have planned such learning outcomes that anticipate the solution of problem situations and inquiry-based activities which needs the integration of the knowledge and skills of two or more school subjects that is characteristic of interdisciplinary education. Besides, the school subjects chosen for the study are important in the aspect of multicultural environment where the diversity of cultures in the society and the education environment enrich the content of learning and the pupils' learning experience.

It is possible to conclude that interdisciplinary education in these curricula is implemented only partly. Interdisciplinary education is evident in the expected learning outcomes that envisage the acquisition of inquiry skills and skills of solving the problem situations. However, they do not emphasize the application of knowledge and skills acquired in other school subjects. This can be foreseen only from the context. The presence of interdisciplinary education is most observed in the curricula of biology and geography, which also include the integration of the knowledge of mathematics, history, social sciences, ethics, IC technologies (computers). Equal attention is paid to inquiry-based activities and solutions of problem situations. The context allows concluding that pupils also use their own experience that they have developed in the multicultural environment of the modern society (Table 1). 
It is surprising that interdisciplinary education is little evident in the literature curriculum. It can be seen in the integration of knowledge and skills acquired in such subjects as history, social sciences, IC technologies (computers). However, the inquiry-based activities and solutions of problem situations are included in the expected learning outcomes comparatively less than in the curricula of other analysed subjects. Pupils' multicultural experience is little used here. But it is exactly this experience that enriches interdisciplinary education.

Table 1

Analysis of the planned learning outcomes of the curricula in the view of interdisciplinary education

\begin{tabular}{|c|c|c|}
\hline $\begin{array}{l}\text { Curri- } \\
\text { culum }\end{array}$ & Inquiry-based activity & Solutions of problem situations \\
\hline 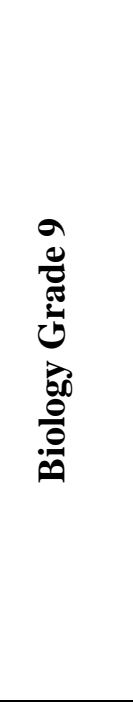 & $\begin{array}{l}\text { Obtain information from reference sources } \\
\text { (books, handbooks, encyclopaedias, journals, } \\
\text { newspapers, information booklets), specific } \\
\text { sources of information (advertisements, TV } \\
\text { commercials, food labels). } \\
\text { Summarize, arrange the obtained data in } \\
\text { tables and graphs. } \\
\text { Assess the credibility of data, their } \\
\text { correspondence to sources of literature, to } \\
\text { data obtained by other pupils. } \\
\text { Explain the differences. } \\
\text { Interpret and explain the obtained results, } \\
\text { formulate conclusions and predict further } \\
\text { application of the obtained results. Observe } \\
\text { the rules of good performance/presentation. }\end{array}$ & $\begin{array}{l}\text { Form the understanding about the } \\
\text { importance of a healthy lifestyle in } \\
\text { human life. } \\
\text { Assess the domestic risk situations } \\
\text { (traumas, poisoning, and intoxication). } \\
\text { Choose season-appropriate clothes. } \\
\text { Assess the risk situations and act } \\
\text { accordingly in extreme conditions. } \\
\text { Are aware of the necessity of biology } \\
\text { knowledge and skills in everyday life, } \\
\text { basic health support and continuation } \\
\text { of education. }\end{array}$ \\
\hline 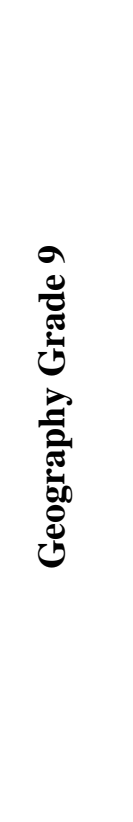 & $\begin{array}{l}\text { Explore which the sources of water pollution } \\
\text { of lakes, rivers and other water bodies in the } \\
\text { local vicinity are and take care of their } \\
\text { protection. } \\
\text { Are able to perform independently } \\
\text { observations in nature and make descriptions } \\
\text { about nature and culturally historical objects. }\end{array}$ & $\begin{array}{l}\text { Using the statistics, analyse the level } \\
\text { of unemployment in regions, towns } \\
\text { and cities of Latvia. } \\
\text { Analyse the causes and problems of } \\
\text { people's migration in the territory of } \\
\text { the country and are aware of the } \\
\text { problems related to it. } \\
\text { Analyse the main nature protection } \\
\text { problems in places of extraction } \\
\text { mineral deposits. } \\
\text { Assess the construction of new } \\
\text { industrial enterprises in Latvia giving } \\
\text { examples, are aware of factors } \\
\text { influencing their construction. } \\
\text { Assess the construction of the } \\
\text { international main road Via Baltica } \\
\text { and are aware of its importance in the } \\
\text { international relations. }\end{array}$ \\
\hline
\end{tabular}




\begin{tabular}{|c|c|c|}
\hline $\begin{array}{l}\text { Curri- } \\
\text { culum }\end{array}$ & Inquiry-based activity & Solutions of problem situations \\
\hline 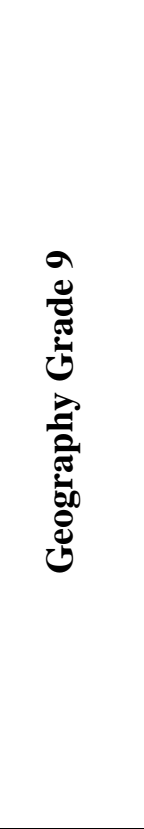 & $\begin{array}{l}\text { Explore which the sources of water pollution } \\
\text { of lakes, rivers and other water bodies in the } \\
\text { local vicinity are and take care of their } \\
\text { protection. } \\
\text { Are able to perform independently } \\
\text { observations in nature and make descriptions } \\
\text { about nature and culturally historical objects. }\end{array}$ & $\begin{array}{l}\text { Using the statistics, analyse the level } \\
\text { of unemployment in regions, towns } \\
\text { and cities of Latvia. } \\
\text { Analyse the causes and problems of } \\
\text { people's migration in the territory of } \\
\text { the country and are aware of the } \\
\text { problems related to it. } \\
\text { Analyse the main nature protection } \\
\text { problems in places of extraction } \\
\text { mineral deposits. } \\
\text { Assess the construction of new } \\
\text { industrial enterprises in Latvia giving } \\
\text { examples, are aware of factors } \\
\text { influencing their construction. } \\
\text { Assess the construction of the } \\
\text { international main road Via Baltica } \\
\text { and are aware of its importance in the } \\
\text { international relations. }\end{array}$ \\
\hline 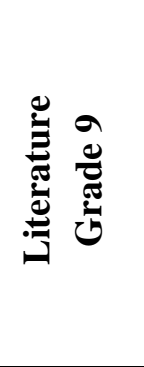 & $\begin{array}{l}\text { Form the research skills, work out the } \\
\text { assessment criteria of the research work, and } \\
\text { assess one's own work and work done by } \\
\text { others. } \\
\text { Uses purposefully the traditional electronic, } \\
\text { audio visual sources of information to } \\
\text { perform the research work. }\end{array}$ & $\begin{array}{l}\text { Express attitude to the issues included } \\
\text { in the literary work, compare it with } \\
\text { one's own life experience. } \\
\text { Analyse the cultural historical facts } \\
\text { included in the literary works and the } \\
\text { link of the literary work with the time } \\
\text { of its writing and the author's } \\
\text { personality. }\end{array}$ \\
\hline
\end{tabular}

More attention to the solution of problem situations is paid in the History of the world subject; it develops critical thinking and decision-making skills on the basis of the knowledge acquired also in other subjects - geography, biology social sciences, ethics, IC technologies (computers). Here pupils have to use their experience that has developed in the multicultural environment of the society. The analysis of this experience enriches interdisciplinary education, forms a broad general world outlook and leads pupils into the life-long and life-broad learning process.

\section{Conclusions}

The multicultural environment of each country that has developed historically now has changed under the influence of the globalization processes in the world. Researchers are more and more speaking about multiculturalism, multicultural education that facilitates successful inclusion of every individual in the globalized society.

School as a model of a multicultural world can promote people's awareness to multiculturalism. The interdisciplinary approach is a key concept to the advancement of school curriculum at all levels. Interdisciplinarity starts on the level of scientific research and then it extends to the field of education. Interdisciplinary education is characterised as the process in which pupils integrate information, methods, tools, perspectives, possibilities, ideas, concepts and theories from two or more fields in order to create "products", explain the phenomenon or solve problems. Interdisciplinary education is implemented also through inquiry-based activities and the solution of problem situations in the current separate subject curricula.

The analysis of the expected learning outcomes of four basic education subject curricula in Grade 9 (biology, geography, history of the world, literature) showed that interdisciplinary education is implemented only partly. It is most broadly and diversely implemented through inquiry-based activities and solution of 
problem situations in biology and geography school subjects but little in literature. Pupils are encouraged to use also their own experience when seeking solutions to problem situations in the History of the world.

The knowledge and skills acquired in several school subjects as well as transversal skills that become more and more topical are applied in the inquiry and the solution of problem situations if we think about a complex use of the knowledge and skills acquired during the schooling in the life-long and life-broad learning in the society of today and future that is characterised by ethnic and cultural diversity, multicultural world.

\section{Bibliography}

1. Boix-Mansilla V. (2010). Learning to synthesize: the development of interdisciplanry understanding. In R. Frodeman, J. Thomson-Klein, C. Mitcham, J.B. Holbrook (Eds.), The Oxford Handbook of Interdisciplanry. Oxford: Oxford University Press, 288 - 306. Retrieved from https://msu.edu/ orourk51/860-Phil/Handouts/Readings/BoixMansilla-LearningToSynthesizeOUP_HoI-2010.pdf

2. Connerley M.L., Pedersen P.B. (2005). Leadership in a Diverse and Multicultural Environment: Developing Awareness, Knowledge, and Skills. ( $1^{\text {st }}$ ed.). California: SAGE Publications.

3. Cooper R. (2003). The Breaking of Nations. Order and chaos in the twenty-first century. London: Atlantic Books.

4. Cox T.H. (1994). Cultural Diversity in Organizations: Theory, Research and Practice. San Francisko: Berrett-Koehler.

5. Duerr L.L. (2008). Interdisciplinary Instructions, Educational Horizons. Educational Horizons, 86(3), 173-180.

6. Farivar S. (1993). Continuity and change: Planning an integrated history-social science/Englishlanguage arts unit. Social Studies Review, 32(2), 17-24.

7. Fox J.A., Baloy N., Sens A. (2014). Mix and Match: Promoting Interdisciplinary Teaching, Learning, and Comunity through Classroom-level Partnerships. Collected Essays on Learning and teaching, 7(2), 142-148. Retrieved from https://celt.uwindsor.ca/ojs/leddy/index.php/CELT/article/download/3977/3288

8. Fraser N., Honneth A. (2003). Redistribution or Recognition? A Political-philosophical Exchange. London: Verso.

9. Gordina M. (2015). Piektdala Latvijas jauniesu ir izteikti multikulturalas personibas, kuri ir atverti sadarbibai ar citam kulturam (A fifth of Latvia's young people are explicitly multicultural personalities who are open to cooperation with other cultures). Riga: Biznesa augstskola Turiba. Retrieved from http://www.turiba.lv/lv/aktualitates/piektdala-latvijas-jauniesu-ir-izteiktimultikulturalas-personibas-kuri-ir-atverti-sadarbibai-ar-citam-kulturam/1367/ (in Latvian)

10. Gutman A. (2003). Identity in Democracy. Princeton, US: Princeton University Press and copyrighted.

11. Holloway D., Green L., Livingstone S. (2013). Zero to eight. Young children and their internet use. LSE, London: EU Kids Online. Retrieved from http://eprints.lse.ac.uk/52630/1/Zero_to_eight.pdf

12. Jones C. (2009). Interdisciplinary Approach- Advantages, Disadvantages, and the Future Benefits of Interdisciplinary Studies. ESSAI, 7(26). Retrieved from

https://dc.cod.edu/cgi/viewcontent.cgi?referer=https://www.google.lv/\&httpsredir=1\&article=112 $1 \&$ context=essai

13. Kidron A., Kali Y. (2015). Boundary breaking for interdisciplinary learning. Research in Learning Techology, 23(26496). Retrieved from https://journal.alt.ac.uk/index.php/rlt/article/download/1646/pdf 22

14. Knotts G., Henderson L., Davidson R.A., Swain J.D. (2009). The Search for Authentic Practice Across the Disciplinary Divide. College Teaching, 57(4), 188-196. Retrieved from http://scholarworks.csun.edu/bitstream/handle/10211.2/1739/HendersonLynette200912_01.pdf?se quence $=3$

15. Kokemuller N. (2016). The Definition of Multicultural in the Workplace. California, US.

16. Kymlicka W. (2001). Politics in the Vernacular: Nationalism, Multiculturalism, and Citizenship. Oxford: Oxford Scholarship.

17. Lake K. (1994). Integrated curriculum. School Improvement Research Series, 16. Retrieved from http://educationnorthwest.org/sites/default/files/integrated-curriculum.pdf 
18. Letterman M.R., Dugan K.B. (2004). Team Teaching a Cross-Discilinary Honors Course: Prepartion and Development. College Teaching, 52(2) 76-79. Retrieved from https://ctl.yale.edu/sites/default/files/basic-page-supplementary-materials-files/team teaching.pdf

19. Lombardo J. (2016). Cultural Diversity in the Workplace: Definition, Trends and Examples. Mountain View: Canada.

20. Mathison S., Freeman M. (1994). The Logic of Interdisciplinary Studies. New York: University at Albany. Retrieved from https://www.albany.edu/cela/reports/mathisonlogic12004.pdf

21. Matsagouras I. (2003). Interdisciplinary school knowledge: The notion-centred recreation and the Project plans. Athens: Grigoris.

22. Matsagouras I. (2004). Interdisciplinary in teaching practice: What, why and how? Records of Workshop: Corriculum Framework- Flexible Zone, 98-140.

23. Norton R. (1988). Similarities between history-social science framework and English-language arts framework: What it means for elementary teachers. Social Studies Review, 28 (1), 48-52.

24. Resident population by citizenship and ethnicity at the beginning of the year. (2017). Riga: Central Statistical Bureau of Latvia. Retrieved from http://data.csb.gov.lv/pxweb/en/Sociala/Sociala_ikgad_iedz_iedzskaits/IS0093.px/?rxid=cd

25. Resident population by ethnicity at the beginning of the year. (2017). Riga: Central Statistical Bureau of Latvia. Retrieved from http://data.csb.gov.lv/pxweb/en/Sociala/Sociala_ikgad_iedz_iedzskaits/IS0070.px/?rxid=b6d6 32f4-e2c2-4638-8dbd-6bb64b4c7523

26. Rijsman J.B. (1997). Social diversity: Asocial psychological analysis and some implications for groups and organizations. European Journal of Work and Organizational Psychology, 6(2), 139-152.

27. Skola 2030: atbalsts macibu pieejas mainai (School 2030: support to the transformation of the teaching/learning approach). (2017). Retrieved from https://www.skola2030.lv/par-projektu (in Latvian)

28. Smith B.L., McCann J. (Eds.). (2001). Reinventing Ourselves: Interdisciplinary Education, Collaborative Learning, and Experimentation in Higher Education. Bolton, MA: Anker.

29. Spanhel D. (1999). An Approach to Integrating Media Education into Everyday School Life and Instruction at Secondary School Level. In F. Gundacker (Ed.), Educating for the Media and the Digital Age. Vienna: Austrian Federal Ministry of Education and Cultural Affairs and UNESCO, 155-161. Retrieved form https://www.mediamanual.at/en/pdf/educating media engl.pdf

30. Spelt E.J.H., Biemans H.J.A., Tobi H., Luning P.A., Mulder M. (2009). Teaching and Learning in Interdisciplinary Higher Education: A Systematic Review. Educational Psychology Review, 21, 365-378. Retrieved from https://link.springer.com/content/pdf/10.1007\%2Fs10648-009-9113-Z.pdf

31. Thompson D.E., Di Tomaso N. (Eds.). (1988). Ensuring Minority Success in Corporate Management. New York: Plenum Press.

32. Vasiliki B., Panagiota K., Stavrakouli K.M. (2016). A New Teaching Method for Teaching Economics in Secondary Education. Journal of Research and Method in Education, 6 (2), 86-93. Retrieved from http://www.iosrjournals.org/iosr-jrme/papers/Vol-6\%20Issue-2/Version1/O0602018693.pdf 